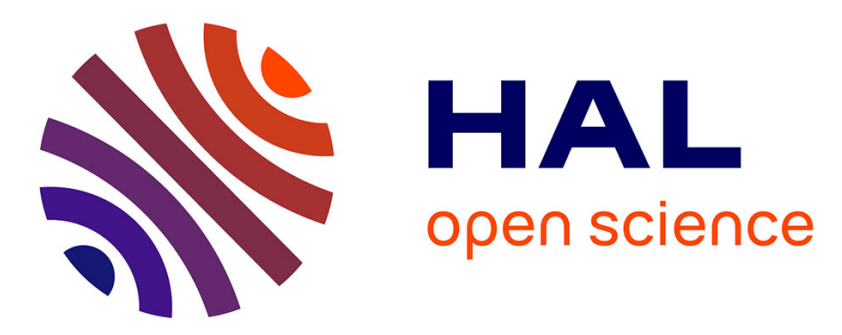

\title{
Rethinking the role of intermediaries as an architect of collective exploration and creation of knowledge in open innovation
}

Marine Agogué, Anna Yström, Pascal Le Masson

\section{- To cite this version:}

Marine Agogué, Anna Yström, Pascal Le Masson. Rethinking the role of intermediaries as an architect of collective exploration and creation of knowledge in open innovation. International Journal of Innovation Management, 2013, 17 (2), pp.1-24. hal-00707376

\section{HAL Id: hal-00707376}

https://hal-mines-paristech.archives-ouvertes.fr/hal-00707376

Submitted on 12 Jun 2012

HAL is a multi-disciplinary open access archive for the deposit and dissemination of scientific research documents, whether they are published or not. The documents may come from teaching and research institutions in France or abroad, or from public or private research centers.
L'archive ouverte pluridisciplinaire HAL, est destinée au dépôt et à la diffusion de documents scientifiques de niveau recherche, publiés ou non, émanant des établissements d'enseignement et de recherche français ou étrangers, des laboratoires publics ou privés. 


\title{
Rethinking the role of intermediaries as an architect ofcollective exploration and creation of knowledge in open innovation
}

\begin{abstract}
This paper questions the applicability of traditional notions of intermediary activities, which are usually categorized aseither brokering or networking, in cases of high uncertainty regarding technologies, markets or which actors to involve. In the case of collaborative openinnovation, especially in circumstances when no single organization is able to take on the challenge alone,the activities traditionally associated with intermediation do not suffice to describe what an intermediary can do to support innovation. This paper presents two cases of intermediaries working withthe early phases of traffic safety innovations, and how they have managed to develop their activities beyond solely brokering and networking, but also to take an active role in the process of joint exploration and creationof knowledge. We use a qualitative approach to analyze the two cases in order to provide examples of how rethinking intermediation activities can support openinnovation in a collaborative setting. The findings suggest that intermediaries taking on a more active role, which could be described as an architect which designs prerequisites and offers leadership in the process of joint exploration and creationof knowledge.
\end{abstract}

Keywords:innovation intermediaries; open innovation; collaborative innovation; case study

\section{Introduction}

Open innovation has rapidly gained ground as an interesting way to open up the innovation process to include more external parties, among practitioners as well as management researchers (Schroll and Mild, 2011, Giannopoulou et al., 2011).Innovation intermediaries, (Hargadon, 1998, Howells, 2006, Diener and Piller, 2010, Stewart and Hyysalo, 2008) as one of many new actors in this field, have come to play an increasingly important role for organizations in their work with open innovation (Chesbrough, 2003).

In the current literature, innovation intermediaries are said to perform a vast variety of activities in the innovation process (see e.g. Howells. 2006 
or Bessant and Rush, 1995) andhave been described e.g. as an agent, broker or marketplace (Chesbrough, 2006) who facilitate the match between a technology and a market.We can broadly characterize these activities as being either brokering e.g. knowledgeor technologies, or establishing networks to facilitate connections among partners. So far, researchers have mainly studied intermediation in caseswhere technologies, actors and markets involved already exist and where relevant actors are able to initiate contacts with intermediaries in order to launch brokering or networking processes. However, it appears that there are cases where those requirements are not met, but where the intermediary has found a new role to play.

One such example is the case whenthere is a desire or need for a larger leap in understanding, new ways of seeing problems, new business models and breakthrough businesses involving a high degree of uncertainty (Damanpour, 1996, Garcia and Calantone, 2002), situations which often require more than one organization to find a solution (Adner, 2006; Powell, Koput, \& Smith-Doerr, 1996), as shown byexamples from health care or renewable energyindustries. Kettunen et al. (2008) emphasize the value of open innovation when trying to achieve breakthrough innovations and Stewart and Hyysalo(2008) claim that typically when there is a large societal demand for innovation, a larger collaboration needs to emerge in order to find a solution, and an intermediary can provide a platform and connections for collaboration.

This paper suggests that in such cases, intermediaries can further perform activities beyond the traditional notion of intermediation in order to utilize the potential in such collaboration. This naturally raises the question of why such an activity should still be regarded as related to the function of an intermediary, and Howells (2006, p 725) pose the question of "when is an innovation intermediary not an innovation intermediary". But, where Howellsrefers to the multitude of additional services that a traditional intermediary can provide to each of its individual clients, we want to emphasis and build further on the role of the intermediary not only as a service provider, facilitator or broker of someone else's knowledge, but also as an architect in form of a co-creator and enabler of collective knowledge creation. 
We present findings from two cases where we argue that such a situation has occurred, and where the intermediaries have played a larger role in the innovation process than what has been described incurrent literature.The two cases, one from France and one from Sweden, depict open innovationintermediaries ${ }^{1}$ working inthe early phases of traffic safety innovation, and we look further into two specific projects aimed at finding new ways of looking at critical problems, in order to explore possible new paths of innovation. The traffic safety field is an area where there is a need for radical innovation as the automotive industry is today in need of renewal in many different directions (Oltra \& Saint Jean, 2009). The casesare somewhat different in their setup, but have the character of "open innovation arenas" (Ollila and Elmquist, 2011), where projects are carried out through collaboration involving a multitude of partners (even competitors). The intermediaries not only provided the necessary infrastructure for the project work, but were also highly influential in the setup, management and progress of the projects. We used a qualitative research approach in order to gain a more profound understanding of the activities taking place in the projects.

The aim of this paper is to explore and characterize how rethinking intermediation activities can support open innovation in a collaborative setting. The research question underpinning this paper is: "How can an intermediary enable collective creation and exploration of knowledge?" The question has been further developed into two sub-questions: "How can such activities be characterized?" and "What are the implications for the role of intermediaries and their management?"

The contribution of this paper is a deepened discussion on the role of intermediaries and we suggest that the traditional concept of intermediation needs to be re-discussed. This paper illustratesthe value of innovation intermediaries taking a more active role, not only in facilitating the innovation process, but actually participating in and co-creating collective exploration and creationof knowledge.

\footnotetext{
${ }^{1}$ We choose the concept of intermediary to describe their role, as that is the closest we can get to an established term that describes the basics of the activities taking place. However, we argue that in the particular projects we studied, activities have taken place beyond their basic objective to serve as a broker or network provider, that expands their role as intermediaries.
} 


\section{Theoretical background}

\section{Innovation intermediaries}

New actors who may be broadly termed as "intermediaries" have emergedin industrial contexts and they now perform a variety of tasks within the innovation process. Scholars in innovation management (Diener and Piller, 2010, Howells, 2006, Hargadon, 1998, Chesbrough, 2006) have addressed such intermediaries, and several studies have tried to characterize the different activitiesthey undertake (Damanpour, 1996, Garcia and Calantone, 2002, Howe, 2006, Howells, 2006, Sieg et al., 2010, Lente et al., 2003, Bessant and Rush, 1995, Stewart and Hyysalo, 2008). In this paper, we use the definition by Howells (2006) as a starting point. He defines an intermediary as "an organization or body that acts as agent or broker in any aspect of the innovation process between two or more parties." (p720).

Within this notion of innovation intermediaries, a large set of actors has been described: bridgers (McEvily and Zaheer, 1999, Bessant and Rush, 1995), brokers (Provan and Human, 1999, Hargadon and Sutton, 1997, Gianiodis et al., 2010, Winch and Courtney, 2007), third parties (Mantel and Rosegger, 1987) and more recently Living labs (Almirall, 2008), animateurs (Howells, 2006), or crowd-sourcing initiatives such as InnoCentive (Sieg et al., 2010, Surowiecki, 2004) (see Howells (2006) for a comprehensive literature review on different forms of intermediaries).

Howells (2006) argues that the research field around intermediaries is quite scattered, and that there is a lack of studies focusing on the holistic role of intermediaries, as many tend to study intermediaries as a marginalized organization or a process in relation to the main subject of interest (e.g. innovation diffusion or innovation systems). Although Howells asks for more theoretically grounded research on intermediaries, and criticizes the pragmatic approach in previous research, it is still vital to keep a close link between the developments in practice and development of theory, to keep the field from diverging into to separate silos. In this line of work, Stewart and Hyysalo (2008) focus on the role of users in different types of intermediaries, showing that intermediaries are generally gathering rather homogeneous actors that are quite close to each 
other both in terms of supplier network and user communities. There can be both benefits and pitfalls in trying to cover a too wide or too narrow span of intermediation activities as well as targeting too large groups, and with the wrong design, intermediaries often fail. Stewart and Hyysalo (2008) argue the need for a different perspective on intermediaries, encouraging emerging methods allowing co-creation withusers. Their main concern is the prevailing emphasis on technological considerations among intermediaries as well as companies, that do not allow space for the participation of existingand new intermediaries.

\section{A typology of innovation intermediation}

Although there have been many words used to describe what intermediaries do, there appears to be a convergence on two main types of actions - broking some kind of contents or networking. "Broker" is defined by the Oxford English Dictionary as "One employed as a middleman to transact business or negotiate bargains between different merchants or individuals". "Networking" is in the same source characterized as "The action or process of making use of a network of people for the exchange of information, etc., or for professional or other advantage“. Thus, neither of the terms has their roots in the field of innovation management. In his seminal paper, Howells (2006) proposed a refined typology of ten innovation intermediation functions (p. 720), based on four main functions described as (1) helping to provide information about potential collaborators; (2) brokering a transaction between two or more parties; (3) acting as a mediator, or go-between, bodies or organizations that are already collaborating; and (4) helping find advice, funding and support for the innovation outcomes of such collaborations.

There have been some recent additions to the functions listed by Howells. A few years ago, several European organizations launched Living Labs initiatives in order to involve users in the innovation process (Bergvall-Kareborn and Stahlbrost, 2009), and have aimed at creating "innovation arenas where multiple actors could experiment in an open, real life environment" (Almirall 2008, p. 2). Thus, intermediaries can impact the network of actors involved in the innovation process. In the 
same type of networking function, crowdsourcing platforms (Sieg et al., 2010, Surowiecki, 2004) help companies to outsource a function once performed by employees to "an undefined (and generally large) network of people in the form of an open call" (Howe, 2006). This notion of influencing the network in order to enhance the innovation processhas also been described by e.g. Callon(1991, 1994).Recent research has pursued this idea and showed how intermediaries can play a third-party role in the formation and maintenance of innovation networks and systems (Klerkx \& Leeuwis, 2009).Social network studies have also shown the importance of network "bridgers" in not only transferring knowledge across structural holes in networks, but as an important source of innovation themselves (Burt, 2004).

It can also be noted that the industries studied are limited, although several argue that an important function for the intermediary is to establish connections between industries. Sieg et al. (2010) studied the chemical industry, Shohet and Prevezer (1996) the biotechnology industry, Klerkx and Leeuwis (2009) the agricultural sector, Seaton and Cordey-Hayes (1993) the defense industry and Stewart and Hyysalo (2008) user innovation in the ICT industry.

As e.g. Seaton and Cordey-Hayes (1993) state, the provision of ideas is only one part of the technology transfer process - a process that in reality much more complex. In this paper, in order to provide a schematic overview of the activities, we have summarized andgeneralizedthe functions ofintermediaries: "brokering contents" as enhancing an existing innovation process by providing various contents and the function of "networking" as providing the right network conditions for a defined innovation goal. We acknowledge the fact that such a clear distinction between brokering and networking can seem artificial, but it provides a conceptual view that helps to clarify intermediation processes, even though they are in practice more complex. A summary of the two main types of intermediation activitiescan be found in table 1 . 
Table 1 Intermediation as described in recent literature

\begin{tabular}{|c|c|c|c|}
\hline Intermediation & Activities & Description & References \\
\hline \multirow[t]{4}{*}{ Brokering contents } & $\begin{array}{l}\text { Providing } \\
\text { information }\end{array}$ & $\begin{array}{l}\text { Foresight and } \\
\text { diagnostics; scanning } \\
\text { information }\end{array}$ & $\begin{array}{l}\text { Howells, 2006, } \\
\text { Hargardonand Sutton, } \\
\text { 1997, Seaton and Cordey- } \\
\text { Hayes (1993) }\end{array}$ \\
\hline & $\begin{array}{l}\text { Brokering a } \\
\text { transaction }\end{array}$ & $\begin{array}{l}\text { Knowledge and } \\
\text { technology processing }\end{array}$ & $\begin{array}{l}\text { Howells 2006, Hargardon } \\
\text { 1998, Provan and Human, } \\
\text { 1999, Winch and } \\
\text { Courtney, } 2007\end{array}$ \\
\hline & Mediating & $\begin{array}{l}\text { Ensuring a lasting } \\
\text { work relationship, } \\
\text { managing IP and } \\
\text { commercialisation } \\
\text { process }\end{array}$ & $\begin{array}{l}\text { Howells 2006, } \\
\text { MantelandRosegger, } \\
\text { 1987, Shohet and } \\
\text { Prevezer, } 1996\end{array}$ \\
\hline & $\begin{array}{l}\text { Evaluating and } \\
\text { setting standards }\end{array}$ & $\begin{array}{l}\text { Testing, accreditating, } \\
\text { evaluing }\end{array}$ & $\begin{array}{l}\text { Howells, 2006, Mantel } \\
\text { andRosegger, } 1987\end{array}$ \\
\hline \multirow[t]{2}{*}{ Networking } & $\begin{array}{l}\text { Providing an } \\
\text { innovation arena for } \\
\text { collaboration }\end{array}$ & $\begin{array}{l}\text { User involvement, } \\
\text { crowdsourcing }\end{array}$ & $\begin{array}{l}\text { Sieg et al., 2010, } \\
\text { Surowiecki, 2004, Howe } \\
\text { 2006, Almirall 2008, } \\
\text { Stewart and Hyysalo, } \\
\text { 2008, Bergvall- } \\
\text { KarebornandStahlbrost, } \\
2009\end{array}$ \\
\hline & $\begin{array}{l}\text { Increasing } \\
\text { connectivity }\end{array}$ & $\begin{array}{l}\text { Formation and } \\
\text { maintenance of } \\
\text { innovation networks } \\
\text { and systems }\end{array}$ & $\begin{array}{l}\text { Callon, 1994, Klerxxand } \\
\text { Leeuwis, 2009, Seaton } \\
\text { and Cordey-Hayes, 1993, } \\
\text { Burt, } 2004\end{array}$ \\
\hline
\end{tabular}

To further explore the way brokering and networking are described and under which circumstances, we analyze the two main types of activities in terms of initiation, outcomes, process, and resources mobilized (table 2). 
Table 2 Analysis of brokering and networking intermediation

\begin{tabular}{|c|c|c|}
\hline Intermediation & Brokering & Networking \\
\hline Initiation & $\begin{array}{l}\text { One organization initiates contact } \\
\text { with the intermediary }\end{array}$ & $\begin{array}{l}\text { One or several organizations initiate } \\
\text { contact with the intermediary }\end{array}$ \\
\hline Outcome & $\begin{array}{l}\text { Contents (knowledge, technologies) } \\
\text { are transferred between two or more } \\
\text { parties }\end{array}$ & $\begin{array}{l}\text { The connectivity of the network is } \\
\text { improved }\end{array}$ \\
\hline Process & $\begin{array}{l}\text { Matching a demand with an offer and } \\
\text { combining existing ideas or } \\
\text { knowledge }\end{array}$ & Linking and coordination meetings \\
\hline Resources & $\begin{array}{l}\text { Reactivity, market expertise, } \\
\text { technology expertise }\end{array}$ & $\begin{array}{l}\text { Multiple connections to experts within } \\
\text { as well as outside the industry }\end{array}$ \\
\hline
\end{tabular}

We conclude that these activities all rely on the intermediaries'capability to find existing offers to express demands and to connect actors regarding a known and well-defined issue. However, what happens when those requirements are not there? In some cases of collaboration in the fuzzy front end of innovation (Reinertsen and Smith, 1991; Khurana and Rosenthal, 1998; Reid and De Brentani, 2004), both the network and the innovation topic itself have to be designed, as technologies, knowledge, market and network of relevant actors are not known or do not yet exist. Indeed, the front end of innovation refers to the ideation phase of innovation, where opportunities, ideas, concepts are considered and then can be refined and developed during the new product development process (Khurana and Rosenthal, 1998). The front end of the innovation process therefore implies a high degree of uncertainty, brokering and networking activities become complex : who are the actors to involve in such situations ? how can brokering occur when neither demand or offer already exist ?Moreover,in the front end of innovation, exploration activities (exploration of new ideas, of new concepts) are needed to propose new products, new services.

\section{Intermediation in collaborative innovation in the fuzzy front end}

In some cases, a single organization is not able to produce innovation by itself and a larger collaboration is needed in order to achieve innovation.For instance, the literature on business ecosystems (Adner, 
2006; Adner and Kapoor, 2010; Iansiti and Levien, 2004; Moore, 1993) has underlined the interdependences that exist among various actors, and has shown in many different industries how "ecosystems allow firms to create value that no single firm could have created alone" (Adner, $2006 \mathrm{p}$. 1). The same argument has been also proposed by scholars in the field of inter-organizational collaboration (Powell et al., 1996), who stated that the locus of innovation is to be found in networks, rather than within on single organization.

Thus, in cases where there is a large societal need for collaborative innovation, academia, industries, institutions, market prescribers, financers have to collaborate in order to explore new solutions to critical societal issues. The intermediations that are required are therefore not bilateral anymore and can take place in a more collective setting. As such, we argue that intermediaries are then put in a position where they can perform activities beyond the traditional notion of brokering or networking in order to utilize the potential in such collaboration.

According to the literature, intermediaries typically act in situations where the innovation topics are clear and shared among a well-identified network, and therefore should not have a role to play in cases where there are greater uncertainties and risks involved.Yet, in cases of innovation in the fuzzy front end, networks and brokered knowledge and ideas still have to be designed. The theoretical overview shows that there is a need to explore what role intermediaries can play in the cases where no single organization canrealize the innovationprocess by it-self.

\section{Methodology}

A case study approach

As our interest in this paper is to get to get a better understanding of the types of intermediation activities carried out, we chose an exploratory research design (Yin, 2003; Eisenhardt,1989). The qualitative, case study approach (Yin, 2003, Bryman and Bell, 2007, Flick, 2009, Eisenhardt, 1989, Lee, 1999) was thought suitable as it provides a way to gain a more profound understanding of the innovation intermediaries as well as their involvement in innovation processes. Therefore, our intent is to uncover a 
new intermediation and to state the limits of brokering and networking in cases of collaborative innovation in the fuzzy front end. To do so, mobilizing a case study approach seems relevant as single cases can be usedas counterexamples that enable the development of existing theory by unveiling gaps and makings suggestions for further research(Siggelkow, 2007).

This paper builds on findings from two complementary case studies of open innovation arenas working with traffic safety in Sweden (SAFER) and in France (Mov'eo). In both cases, the intermediaries are a result of state-funded initiatives, which were set-up to promote collaborative research on this subject as it concerns several actors in society as well as the general public. We chose to analyse two cases to explore cross-case patterns. As stated by Eisenhardt (1989), such research design forces researchers to look for differences between cases that seem to be similar, and helps to break simplistic frameworks (p.544).

We narrowed our scope to look at one project in each arena: SEVS at Safer and 2WS at Mov'eo. The projects were selected according to Yin's (2003) "extreme case" selection strategy, where the selected projects were thought to have unique qualities : they took place in a very collaborative setting, societal demand for innovation was strong, uncertainty was high, and a new role was played by intermediaries who did not act as usual, i.e. as broker or networker. This provided an opportunity to see new types of intermediary activities related to collaborative exploratory innovation processes.

\section{Methods of data collection}

The data collection for the SEVS case study was conducted during Sept 2010 to Jan 2011. In total 9 semi-structured interviews, about 1 hour each, with people involved in the core team or management of SEVS and SAFER were conducted. The interviews revolved around the execution of the project and the participants' views on the methods used in the process. Some project documentation and presentation material etc. were also reviewed.

The case study of the 2WS project was conducted during Oct 2008 to June 2009. Semi-structured interviews with people involved in the core team atMov'eo were conducted. Observations of three workshops 
complemented those interviews, and access to 32 other European projects was granted.

\section{Method of data analysis}

The data from the projects wereanalyzed according to the pre-defined dimensions found relevant from the literature review in order to characterize the intermediation activities; initiation, outcome, process and resources. This approach allowed to see to what extent the activities carried out in the SEVS and 2WS project differed from intermediation activities previously described.

\section{Case findings}

SAFER - an open innovation arena for vehicle and traffic safety

SAFER is auniversity-hosted research centre in Gothenburg, Sweden, with a mission to function as an open innovation arena. At SAFER, 22 organizations from academia, industry and government authorities cooperate in order to create innovations in traffic and vehicle safety. SAFER is set upas a platform and facilitator of collaborative projects, and offers office facilities, meeting rooms, seminars and conferences etc. to their members.SAFER is not an organization in the judicial sense, but is more like an association consisting solely of its members, governed by an annual meeting of the partners and an elected board. Thus, without the partners, there would be no organization and no one to perform any work, which differentiates SAFER from an intermediary in the traditional sense. The small staff needed to maintain the daily managerial work of SAFER is employed by the university partner. The partners use SAFER as an umbrella organization to seek external funding, as the small start-up grant that SAFER has received from Swedish authorities is not enough for all the projects. In total 82 projects are either finished or on-going at SAFER (August 2011) and approximately 170 people currently has access to the SAFER offices.

The projects at SAFER can be of different magnitude, ranging from minor pre-studies to large-scale testing projects or method development. The 
collaborating partners pitch ideas on new projects to the other partners, in order to find collaborators. On some occasions, collaborators are found outside of the boundaries of SAFER, where the extensive network of SAFER can be of good use.Thus, the role of SAFER is to provide a meeting space for matchmaking and networking, and offer neutral grounds for the projects to meet and work.

The selected project at SAFER: SEVS

SEVS (Safe, Efficient Vehicle Solutions) was a project co-hosted by SAFER and The Swedish Hybrid Vehicle Centre (SHC) from autumn 2009 to summer 2010. The aim of the project was to define possible scenarios for the future of Electric and Hybrid Vehicles, based on trends and tendencies seen in the world today. Research in the automotive industry oftenputs the vehicle in focus, but the project team of SEVSdecided early on to adopt a more holistic approach in which the vehicle is regarded as a component in a much larger traffic system. While technological uncertainties make it impossible to determine today what will be the right automotive engineering solution in 2030, uncertain social factors play an even bigger part, and there was a belief that it was necessary to increase the understanding about these factors. This holistic and multidisciplinary approachto the problem separated this project from most other SAFER projects.

Table 1 Key information regarding the SEVS project 


\begin{tabular}{ll}
\hline Project duration & August 2009- June 2010 \\
Number of partners & $\begin{array}{l}16 \text { partners, approximately 20 core team members and } 100 \text { persons involved as } \\
\text { work force, mainly engineers, researchers and designers from the partner }\end{array}$
\end{tabular}


Participating organizations

Management structure

Project manager

The role of SAFER in the project

External financiers

Main results

Reporter and beneficiaries of main result

Continued action organizations

AB Volvo, Autoliv, Chalmers, Energimyndigheten, Epsilon, Etteplan, Saab Automobile AB, SAFER, Scania, Semcon, Swedish Hybrid Vehicle Centre (SHC), Swedish Governmental Agency for Innovation Systems, SP Technical Research Institute of Sweden, Swerea SICOMP, Viktoria Institute, Volvo Car Corporation, VTI

Management group with key members of SAFER and SHC, assisting the project manager in strategic decisions. A technical project manager working beside the main project manager. Work force with a core project team continuously involved in workshops and distributing work to relevant personnel.

Main project manager a consultant with focus on sustainability with background in automobile industry. Head hunted by SAFER to spearhead the project. Technical project manager from one of the participating partner organizations.

In November 2008, SAFER and the Swedish Hybrid Vehicle Centre (SHC) hosted a seminar on the issue of the future of the transportation system, which resulted in a joint application for research funding to start the SEVS project. During the project, SAFER had an active role in the management group and supporting this new type of project. The high level of involvement from SAFER management was unusual compared to other SAFER projects, but was considered necessary due to the nature and the strategic value of the project. Thus, SAFER did not only provide infrastructure for the project but also a sense of direction and support in the chosen methodology.

Swedish Energy Agency, Swedish Governmental Agency for Innovation Systems

4 scenarios depicting possible futures for transportation systems depending on different drivers of change. The scenarios also included 7 virtual concept vehicles. Further, a number of technical reports specifying technical requirements and outlining essential research questions for a possible continuation was delivered.

Project manager responsible for overall reporting to SAFER, SHC and financiers. Final results presented at a seminar in June, 2010. Continuous reporting during the project by team members into their respective partner organization.

SEVS part II, with focus on setting the research agenda based on the 4 scenarios and research questions identified in phase I, launched in late 2011.

\section{Initiation}

The project was initiated by and within SAFER, as opposed to initiated by only one partner organization, and motivated by societal concerns and a 
realization that this type of projects could not successfully be carried out by only one organization. Providing insights on the future of transport systems was an issue that was not typically at the agenda of the members of SAFER, but the organization felt the need to initiate a project anyway. This resulted in a space for several organizations to collaborate to find new, radical solutions to complex problems.

\section{Outcomes}

\section{New knowledge and new paradigms}

The project managed to use the open innovation arena as a stepping stone for undertaking a futuristic and different approach that did not only focus on solving the current problem but in reality re-defined the problem formulation by putting it in a larger context.The outcome waspreviously unthought-of ideas, such as the concept of "sustainable transportation systems".

The project management pushed participants to share knowledge and to go beyond what they were already familiar with. The SEVS project looked into drivers of change in the transportation system, something that no automotive project known to SAFER had done before. Depending on if one regards the drivers of change as individual or political could have significant impact on how the transportation system will look in the future.

\section{A creative climate}

A good creative climate is vital in any type of organization interested in being innovative (Amabile, 1996, Ekvall, 1996, von Stamm, 2008). Five major organizational factors are said to influence creativity and innovation in the work environment; organizational climate, organizational culture leadership style, resources and skills, and the structure and systems of an organization (e.g. Amabile et al., 1996, Ekvall, 1996).

For the managing team from SEVS, fostering a creative climate was essential in order to organize an open innovation collaboration that would enableinnovative ideas to develop. The project was successful in establishing a creative climate according to the participants, as is illustrated by this quote from a SEVS team member:

"Somehow a very trusting relationship was built, which allowed us to dare to be open, Some would certainly say, if they walked into the 
room at that time, that what was going on there was a load of crap, loose speculation, but I have come to know myself well enough to know that that is how knowledge is created". Ted, team member SEVS

\section{Process}

The SEVS project used a nine step-methodology providedby Malmeken $\mathrm{AB}(\odot)$ and used specifically for dealing with complex problems. The project was driven forward by a number of seminars with invited speakers and workshops where the project members worked together systematically on each of these points:

- Identify future stakeholders (individuals, organizations, business, etc.)

- Identify requirements and expectations concerning how future transportation solutions meet the different categories of stakeholders' mobility needs.

- Identify future mobility needs for transporting goods as well as people

- Societal perspective: Requirements and expectations concerning the construction/development of future sustainable road transportation solutions.

- Engineering perspective: Requirements and possibilities concerning the construction/development of future sustainable road transportation solutions.

- Transportation solutions were described in terms of products (e.g. vehicle concepts) and services (pro-active safety, third-party ticketing etc).

- Identify products and services

- Identify critical research questions that need answers

- Identify potential strategic partnerships

The SEVS team members claim they appreciated the approach, as it got them thinking in ways they never thought of before and they had the opportunity to work with new people. The downside was that the method included plenty of meetings and was very therefore resource demanding. The interviewees claim it was very rewarding for their own personal development to work in this way, but some felt guilty that not more 
tangible results than the scenario descriptions have been presented to their home organizations, as clear, applicable outcomes are usually required to legitimize participation in these types of projects. Although most SEVS partners were positive towards the results of the project, the debate regarding if it was worthwhile has been unavoidable. If they were to do it over again, some interviewees were not certain that their organizations would participate, which underlines the challenge of legitimizing a controversial approach to organizations under pressure to keep budgets tight.

\section{Resources}

In terms of what was required to make this project possible, the management team appear to have had a crucial role. In this case, management had to get deeply involved in what was discussed within the projects and "get their hands dirty" in order to steer the project in the "right" direction. The SEVS project manager, with great experience and passion for sustainability issues, provided amodel for structuring the process and therefore influenced the issues put up for discussion.

Furthermore, management had to get participants involved in the process, even though the main targets were not always clear to them: the project manager struggled in the beginning to make the participants see the value of the chosen approach, but eventually managed to convince them it was worthwhile.

\section{Mov'eo - a "Pole of competitiveness" on private and public transport}

Mov'eo is a "Pole of competitiveness" (Pôle de compétitivité), part of a French state-funded initiative that aims at reinforcing the uniqueness of local economies and the attractiveness of regions in France. The aim of Mov'eo isto foster the development of collaborative and innovative projects around private and public transport. Mov'eo is divided in several branches that address different themes. One of them is the branch "Road safety", whose purpose is to improve road safety for all types of users in the city and on the road. Since its launch in 2006, Mov'eo has gathered over 300 organizations as members and labelised $218 \mathrm{R} \& \mathrm{D}$ projects. 
Mov'eo's purpose is to help diverse actors (firms, research labs, entrepreneurs, institutions) to collaborate on projects and to help them apply for funding. (116 projects out of the 218 projects certified since 2006 have received state financing, for a budget exceeding 200 million euros). To achieve such a goal, Mov'eoprovides a series of services for its members: meetings and workshops proposals, communication tools (newsletter, technology watch), support in collaborative projects (finding the right expertise, consultants, financers). Hence, Mov'eo provides means to improve the connectivity of the network through regular meetings and acts as a broker for firms that lack some competences.

The selected project at Mov'eo: 2 WS (two-wheelers' safety)

The project called 2WS (two-wheeler safety) deals with road safety for two-wheeled vehicle. This issue is a crucial public health issue, as road accidents are the third most common cause of death in France. In total, 12 organizations provided about 60 persons participating in this project for 8 months, from autumn 2008 to summer 2009.

This project required Mov'eoto shift focus in its activities, and it was handled by two master students specialized in innovation management and design, involved in the European Centre of studies on safety and risk analysis, (or Centre Européend'Etudes de Sécurité et d'Analyse des Risques - (CEESAR)).

One of the outcomes of the project was the definition of a new model of road safety adapted to $2 \mathrm{WS}$ : interactive road safety. In the case of $2 \mathrm{WS}$, in more than $70 \%$ of cases, the accident occurs with an interaction with another vehicle. When it comes to road safety for two wheels, the interactions are always present, as there are interactions between drivers, interactions between systems, interactions between drivers and systems, and these need to be considered when suggesting appropriate measures for increasing safety for two-wheelers.

Table 2 Key information regarding the $2 \mathrm{WS}$ project 
Initiation

\begin{tabular}{|c|c|}
\hline Project duration & November 2008 - June 2009 \\
\hline Number of partners & $\begin{array}{l}\text { Over } 30 \text { partners, and } 70 \text { persons involved as work force, mainly engineers, } \\
\text { researchers and designers from the partner organizations }\end{array}$ \\
\hline $\begin{array}{l}\text { Some of the } \\
\text { participating } \\
\text { organizations }\end{array}$ & $\begin{array}{l}\text { Research labs (CEESAR, INRETS), Institutions (Paris City Hall, French } \\
\text { Construction Governmental Agency, Firemen, Emergency medical service, ...), } \\
\text { Firms (Honda, Peugeot, Decathlon, ...) and Associations (Biker association, } \\
\text { care sharing association, ...) }\end{array}$ \\
\hline $\begin{array}{l}\text { Management } \\
\text { structure }\end{array}$ & $\begin{array}{l}\text { Management group with two students from Ecole des Mines de Paris, assisting } \\
\text { the manager of the "road safety" axis of Mov'eo. The students reported to their } \\
\text { managing team at Ecole des Mines every week for at least } 2 \text { hours. }\end{array}$ \\
\hline Project manager & The two students had training in innovation management and design. \\
\hline $\begin{array}{l}\text { The role of Mov'eo } \\
\text { in the project }\end{array}$ & $\begin{array}{l}\text { Early in } 2008 \text {, a report on road safety for two-wheelers was ordered by French } \\
\text { government. The result was enlightening as the title was "Road safety for two- } \\
\text { wheelers, a matter of urgency". In June } 2008 \text {, the pole Mov'eo launched an } \\
\text { initiative to help the actors of the industry to explore new paths of innovation on } \\
\text { the matter in a collective context. }\end{array}$ \\
\hline Main results & $\begin{array}{l}\text { The two main results are : (1) re-discussed commonly accepted knowledge (the } \\
\text { fact that two-wheeler safety is the matter of bike and bike accessories } \\
\text { manufacturers (2) proposals of new paradigms, such as "interactive road safety" }\end{array}$ \\
\hline Continued action & Since this project, the involvement of Mov'eo on the matter has decreased. \\
\hline
\end{tabular}

The projectwas initiated and hosted by Mov'eo, as opposed to initiated by only one partner organization, andmotivated by societal concerns on twowheelers safetyin a collaborative setting. Providing insights on the possible paths of innovation on two-wheeled road safety wasan issue that was not typically handled byMov'eo, but the organization felt the need to initiate a collaborative project anyway.

\section{Outcomes : new knowledge and new paradigms}

The projectallowed exploration in many directions, and as such enableddiscussions among the participants around innovative perspectives. The outcome wasradicallynew ideas, such as the model of "interactive road safety".

Moreover, participants involved in those structure-challenging projects re-discussed commonly accepted knowledge: 
and proposing new paradigms:

"interactions are of paramount importance in two-wheel vehicle accidents" or "sustainable cars are not safe, as weight is a crucial factor for both conditions, but at opposite ends of the scale"

The students managing the projectpushed participants to share knowledge and to overcome the classical ideas they had regarding twowheelers safety. Thus, participants of the 2WS, with the help of the students, discovered two examples of projects re-discussing the interactions between a two-wheelers and a third party, one in Malaysia (where traffic is organised with separate flows for cars and for bikes) and one in the Netherlands (where a few villages' infrastructure does not include any traffic signs nor pavement).

\section{Process}

In order to achieve such outcomes, a specific process with a dedicated, thorough methodology was implemented; this methodology was new to the participants.

The team managing the $2 \mathrm{WS}$ project used a specific Collaborative Creative Design Method called "KCP workshops" (Hatchuel et al., 2009, Elmquist and Segrestin, 2009, Arnoux and Béjean, 2010). The project was divided in three phases: (1) one for networking and knowledge sharing, (2) one for conceptual exploration and discussion around novel paths of innovation and (3) one for structuring proposals, and each phase was concluded by a workshop of 4 hours with all the actors involved.

- The purpose of the first phase was to gather knowledge on the subject and the goal was to ensure that everyone shared the same vision of the state of the art.

- The second phasestarted with the vague task to work on "Road safety of two wheels." Because of the broad and indefinite aspect of this concept, they decided to explore it with 3 sub-concepts: Safety by the assailants - Devices that do not stress the driver Unconstrained security . 
- The third phase was a workshop which was more guided, as the management team proposed project themes and asked the participants what they would do to complete these projects.

\section{Resources}

In terms of what was required to make the project possible, we found that management team had a crucial role in helping the particpants to explore new knowledge and new paradigms. To do so, they had to get involved in the contents of the discussion and therefore, go beyond a simple organizer role.

"To push the project forward, we had to go into the contents, to propose new ideas, to help sharing knowledge among the participants. "MartheSouquiere, Student managing the 2WS project at Mov'eo

In the 2WS case, the two students managing the project were the ones who proposed discussion topics during the second phase of the process, subjects such as "devices that do not stress", or "being protected by an aggressor". Furthermore, the management had to get participants involved in the process, even though the main targets were not always clear to them. Besides, managers of the 2WS project involved actors that were not usually included on two-wheelers' road safety issues, such as the user associations or the French Mail Service (La Poste).

\section{Summary of the case description and findings}

Subjects like "possible scenarios for the future of electric and hybrid vehicles" or "two-wheeled road safety" are open questions, that do not fit in common pre-defined representations of what road safety is and who is involved. In this sense, both projects are radical innovation projects. Both projects had a high level of complexity and required the involvement and collaboration of multiple actors. We summarize the cases description in table 3 . 
Table 3 Summary of case description

\begin{tabular}{|c|c|c|}
\hline & SAFER & Mov'eo \\
\hline Description & $\begin{array}{l}\text { A university-hosted research centre } \\
\text { to create innovations in traffic and } \\
\text { road safety }\end{array}$ & $\begin{array}{l}\text { A French state-funded initiative that } \\
\text { fosters the development of } \\
\text { collaborative and innovative projects } \\
\text { around private and public transport }\end{array}$ \\
\hline $\begin{array}{l}\text { Regular } \\
\text { activities }\end{array}$ & $\begin{array}{l}\text { Provide a meeting space for } \\
\text { matchmaking, knowledge sharing } \\
\text { and networking }\end{array}$ & $\begin{array}{l}\text { Meetings, workshops, communication } \\
\text { tools, support to collaborative projects } \\
\text { by finding the needed competences }\end{array}$ \\
\hline $\begin{array}{l}\text { Focal project } \\
\text { in this paper }\end{array}$ & $\begin{array}{l}\text { SEVS (Safe, Efficient Vehicle } \\
\text { Solutions), project to define possible } \\
\text { scenarios for the future of electric } \\
\text { and hybrid vehicles }\end{array}$ & $\begin{array}{l}2 \mathrm{WS} \text { (two-wheeler safety), project on } \\
\text { road safety for two-wheeled vehicle }\end{array}$ \\
\hline
\end{tabular}

Our findings have shown how, in collaborative innovation projects on road safety, SAFER and Mov'eo have performed a type of intermediation that was not predicted by literature, as it is neither brokering contents nor networking.

The context in which this intermediation occurs is different from the other two intermediation activities, where another organization initiates the contact. In cases of explorationactivities, the intermediary in it-self takes an active role in launching collaboration and seeking partners among known and unknown actors.

Within such context, the outcome of the involvement of the intermediary in our cases is not only the establishment of a creative climate, but also new visions and new knowledge that questioned established ways of working and taken-for-granted truths. The outcome is then not of enhancing existing processes, but of creating new contents and on utilizing the creative state of mind of the stakeholders in the projects.

To achieve these results, the process in both cases depended on a highly structured methodology that guided the team through the project phases and allowed them to deploy exploration activities, in order to structure and explore new knowledge and new paradigms in a creative climate. Thus, it was not something that happened by it-self, but as the result of utilizing knowledge of how to create radical, ground-breaking 
solutions. Notice that the two methodologies deployed in our cases were not self-evident for either of the intermediary organizations.

The resources necessary for accomplishing this included a deep involvement from management in project issues. Through their commitment the team members opened up to explore new knowledge and engage with new partners. The management also brought with them new, broader visions of what the collaboration could accomplish, which was not the original scope of the existing partners.

We then call "exploring" this new type of intermediation, different from brokering or networking. In these situations where a collaborative innovation process is required, an intermediary can act as an architect of collective exploration and creation of knowledge.

The key elements of three types of intermediations are summarized in table 4 .

Table 4 A new type of intermediation: Exploring

\begin{tabular}{|c|c|c|c|}
\hline Intermediation & Brokering & Networking & Exploring \\
\hline Initiation & $\begin{array}{l}\text { One organization initiates } \\
\text { contact with the } \\
\text { intermediary }\end{array}$ & $\begin{array}{l}\text { One or several } \\
\text { organizations initiate } \\
\text { contact with the } \\
\text { intermediary, who } \\
\text { acts as a central hub } \\
\text { in the network }\end{array}$ & $\begin{array}{l}\text { Several organizations } \\
\text { seek to collaborate on } \\
\text { radical innovation and } \\
\text { lack the right partners. } \\
\text { The intermediary acts as } \\
\text { initiator. }\end{array}$ \\
\hline Outcome & $\begin{array}{l}\text { Contents (knowledge, } \\
\text { technologies) are } \\
\text { transferred between two or } \\
\text { more parties }\end{array}$ & $\begin{array}{l}\text { The connectivity of } \\
\text { the network is } \\
\text { improved }\end{array}$ & $\begin{array}{l}\text { Creative climate, new } \\
\text { visions, new knowledge }\end{array}$ \\
\hline Process & $\begin{array}{l}\text { Matching a demand with } \\
\text { an offer and combining } \\
\text { existing ideas or } \\
\text { knowledge }\end{array}$ & $\begin{array}{l}\text { Linking and } \\
\text { coordination } \\
\text { meetings }\end{array}$ & $\begin{array}{l}\text { Highly structured } \\
\text { creative methodology }\end{array}$ \\
\hline Resources & $\begin{array}{l}\text { Reactivity, market } \\
\text { expertise, technology } \\
\text { expertise }\end{array}$ & $\begin{array}{l}\text { Multiple connections } \\
\text { to experts within as } \\
\text { well as outside the } \\
\text { industry }\end{array}$ & $\begin{array}{l}\text { Involvement in the } \\
\text { project issues, to enrich } \\
\text { visions and explore new } \\
\text { ideas, new partners }\end{array}$ \\
\hline
\end{tabular}




\section{Discussion}

This paper has tried to shed a light upon the type of activity an intermediary can take part into stimulating collaborative radical innovation. In the existing literature defining intermediaries and their roles, e.g. Howells (2006), we noted that an intermediary taking part in collaborative exploratory processes is not an expected or commonly noted behaviour. Stewart and Hyysalo (2008) started a discussion on a new role of intermediaries, which this paper has taken even further. Our cases show that intermediaries can play a valuable and crucial role in collaborative innovation processes and act as an architect of collective exploration.

Although this paper is based on a generalization of intermediation activities, the intention is to show that the process of intermediation is complex. In some cases, it is necessary to explore all possible ways and means of how that process can be supported. Not exploring or discussing the potential role of an intermediary in those situations is ill advised as the world is facing serious challenges.

Our contribution is the identification and characterization of a new type of intermediation, different from the traditional notion of either brokering of networking (e.g. McEvily and Zaheer, 1999, Bessant and Rush, 1995, Provan and Human, 1999, Hargadon and Sutton, 1997, Howells, 2006, Sieg et al., 2010). This new intermediation infers an active role for the intermediary in the innovation process. The cases also underline that the intermediaries are not exclusive in their roles, asactivities such as brokering and networking will probably always be a core part of intermediaries.

At the very heart of this new type of intermediation is structuring collective exploration activies necessary to trigger the participants to go beyond what they already know. The time has come to introduce the concept of "exploring" as one of the core activities of an intermediary, as organizations need guidance on how to approach these complex issues. The intermediary then acts as an architect of such explorations. The findings show that the new type of intermediation is characterized by a high degree of involvement of the intermediary in the projects, a will to generate new ideas and to involve different types of organizations. By doing this, the projects established a creative climate and were able to explore and present new ideas and new knowledge. The refreshing 
approach to project planning and execution can be regarded as inspiring role-models for others, showing that a different approach to intermediation is possible when circumstances demands it.

\section{Conclusions}

Using the illustration of two cases, this paper proposes that intermediaries can fill a valuable role even in innovation processes where the technologies, markets and actors are unknown, where there is a need for collective action beyond the sole firm to explore new possibilities. Thus, the two cases analysed in this paper are counterexamples of what intermediaries traditionally do, as the activities undertaken in the two cases presented here could not have been predicted based on what is currently known about the roles of intermediaries (brokers or networkers). This makes us question if not the frame surrounding intermediation activities should be enlarged.

The type of intermediary described in this paper as an architect of collective exploration highlights the fact that an innovation intermediary can be an initiator, co-creator, manager and stakeholder at the same time in processes dealing with complex issues.

The consequence of identifying this new type of intermediation is that it can open new ways of dealing with issues that were previously left unsolved, and the structured methodologies applied in both our cases are examples of collective creative frameworks that could be an inspiration for other projects.

The rapid increase in collaborative arenas and the emergence of new actors having to manage them, such as cluster managers, have generated a pressing need to consider the managerial implications of different types of intermediation.For an intermediary wishing to expand their role and be more participative, it is necessary to acknowledge the need to specific capabilities required to make it happen, as it will not happen by itself. A creative, open-minded leadership is a crucial requirement, as neither processes nor climate will change as intended without the support of management.

We suggest that future research on the value and application of this new type of intermediation should be undertaken to verify the initial 
findings of this paper. We have investigated a new role that innovation intermediaries can play in the specific situations of collaborative innovation. It would also be interesting to explore other types of intermediation that could be useful in different aspects of the innovation process.

\section{References}

Adner, R. (2006). Match Your Innovation Strategy to Your Innovation Ecosystem. Harvard Business Review.

Adner, R., \&Kapoor, R. (2010). Value creation in innovation ecosystems: how the structure of technological interdependence affects firm performance in new technology generations. Strategic Management Journal, 31(3), 306-333

Almirall, E. (2008). Living Labs and open innovation: roles and applicability. The Electronic Journal for Virtual Organizations and Networks, 10.

Amabile, T. M. (1996). Creativity in Context, Colorado, Westview Press.

Arnoux, F. \&Béjean, M. (2010). Strategies for Building Radical Innovation Potential : Exploring the Role of Collaborative Creative Design Methods. International Product Development Management Conference. June, Murcia, Spain.

Bergvall-Kareborn, B., \&Stahlbrost, A. (2009). Living Lab: an open and citizen-centric approach for innovation. International Journal of Innovation and Regional Development, 1(4), 356 - 370.

Bessant, J. \& Rush, H. (1995). Building bridges for innovation: the role of consultants in technology transfer. Research Policy, 24 (1), 97-114.

Bryman, A. \& Bell, E. (2007). Business Research Methods, Oxford University Press.

Burt, R. 2004. Structural holes and good ideas. American Journal of Sociology, 110, 349-399. 
Callon, M. (1991). Techno-economic networks and irreversibility. Law, J. (Ed.), A Sociology of Monsters: Essays on Power, Technology and Domination (pp. 132-161). London: Routledge.

Callon, M. (1994). Is Science a Public Good? Science, Technology \& Human Values, 19, 395 - 424.

Chesbrough, H. (2006). Open business models: How to thrive in the new innovation landscape, Boston, MA, Harvard Business Press.

Chesbrough, H. W. (2003). Open innovation: the new imperative for creating and profiting from technology, Boston, MA, Harvard Business School Press.

Damanpour, F. 1996. Organizational Complexity and Innovation: Developing and Testing Multiple Contingency Models. Management Science, 42(5, May), 693-716.

Diener, K. \&Piller, F. (2010). The Market for Open Innovation: An Executive Report Structuring the Market for Support and Consultancies for Open Innovation, [n.p.], RWTH-TIM Group

Eisenhardt, K. (1989). Building theories from case study research.Academy of Management Review, Vol. 14 (4), 532-550.

Ekvall, G. (1996). Organizational Climate for Creativity and Innovation. European Journal of Work and Organizational Psychology, 5 (1), 105123.

Elmquist, M. \&Segrestin, B. (2009). Sustainable development through innovative design: lessons from the $\mathrm{KCP}$ method experimented with an automotive firm. International Journal of Automotive Technology and Management, 9 (2), 229-244.

Flick, U. (2009). An Introduction to Qualitative Research, London, Sage Publications.

Forsman, H. (2009). Balancing capability building for radical and incremental innovations. International Journal of Innovation Management, 13 (4), 501-520. 
Garcia, R., \&Calantone, R. (2002). A critical look at technological innovation typology and innovativeness terminology: a literature review. Journal of product innovation management, 19, 110-132.

Gemünden, H. G., Salomo, S. r. \&Hölzle, K. (2007). Role Models for Radical Innovations in Times of Open Innovation. Creativity and Innovation Management, 6 (9).

Gianiodis, P., Ellis, S. C. \&Secchi, E. 2010. Advancing a typology of open innovation. International Journal of Innovation Management, 14 (4), 531572.

Giannopoulou, E., Yström, A., Ollila, S., Fredberg, T. \&Elmquist, M. (2010). Implications of Openness: A Study into (All) the Growing Literature on Open Innovation. Journal of Technology Management \& Innovation, 5 (3), 162-180.

Iansiti, M., andLevien, R. (2004). Strategy as ecology. Harvard Business Review, March 2004, 68-79.

Giannopoulou, E., Yström, A. \& Ollila, S. 2011. Turning Open Innovation into Practice: Open Innovation Research through the Lens of Managers. International Journal of Innovation Management, 15 (3), 505-524.

Hargadon, A. \& Sutton, R. I. (1997). Technology Brokering and Innovation in a Product Development Firm. Administrative Science Quarterly, 42, 716-749.

Hargadon, A. B. (1998). Firms as knowledge brokers. California Management Review, 40 (3), 209-.

Hatchuel, A., Le Masson, P. \& Weil, B. (2009). Design Theory and Collective Creativity: a Theoretical Framework to Evaluate KCP Process. International Conference on Engineering Design, ICED'09, 2009 24-27 August 2009, Stanford CA.

Howe, J. (2006). The Rise of Crowdsourcing. Wired, 14(6).

Howells, J. (2006). Intermediation and the role of intermediaries in innovation. Research Policy, 35 (5), 715-728. 
Kettunen, J., Ilomäki, S.-K. \& Kalliokoski, P. 2008. Making sense of innovation management, Tampere, The Federation of Finnish Technology Industries.

Khurana, A., \& Rosenthal, S. R. (1998). Towards Holistic "Front Ends" In New Product Development. Journal of product innovation management, 15, pp. 57-74.

Klerkx, L. \& Leeuwis, C. (2008). Balancing multiple interests: Embedding innovation intermediation in the agricultural knowledge infrastructure. Technovation, 28 (6), 364-.

Klerkx, L., \&Leeuwis, C. (2009). Establishment and embedding of innovation brokers at different innovation system levels : Insights from the Dutch agricultural sector. Technological Forecasting \& Social Change, 76(6), 849-860.

Lee, T. W. (1999). Using qualitative methods in organizational research, Thousand Oaks, CA, Sage Publications, Inc.

Lente, H. v., Hekkert, M., Smits, S. \&Waveren, B. v. 2003. Roles of systemic intermediaries in transition processes. International Journal of Innovation Management, 7 (3), 247-279.

Mantel, S. \&Rosegger, G. (1987). The Role of Third Parties in the Diffusion of Innovations: A Survey. In:Rothwell, R. \&Bessant, J. (eds.) Innovation: Adaptation and Growth. Amsterdam: Elsevier Science Publishers.

McEvily, B. \&Zaheer, A. (1999). Bridging Ties: A Source of Firm Heterogeneity in Competitive Capabilities. Strategic Management Journal, 20 (12), 1133-1156.

Moore, J. F. (1993). Predators and Prey: A New Ecology of Competition. Harvard Business Review, (May-June), 75-87.

Ollila, S. \& Elmquist, M. 2011. Managing Open Innovation: Exploring Challenges at the Interfaces of an Open Innovation Arena. Creativity and Innovation Management, 20 (4), 273-283.

Oltra, V., \& Saint Jean, M. (2009). Technological Forecasting \& Social Change Sectoral systems of environmental innovation: An application to 
the French automotive industry. Technological Forecasting \& Social Change, 76(4), 567-583

Powell, W. W., Koput, K. W., \& Smith-Doerr, L. (1996). Interorganizational Collaboration and the Locus of Innovation : Networks of Learning in Biotechnology. Administrative Science Quaterly, 41 (1996), 116-145.

Provan, K. G. and Human, S. E. (1999). Organisational learning and the role of the network broker in small-firm manufacturing networks. In:Grandori, A. (ed.) Interfirm Networks: Organisation and Industrial Competitiveness. London: Routledge.

Reid, S. E., \& De Brentani, U. (2004). The Fuzzy Front End of New Product Development for Discontinuous Innovations: A Theoretical Model. Journal of product innovation management, 21(3), 170-184. Blackwell Publishing.

Reinertsen, D. (1994). Streamlining the Fuzzy Front-end. World Class Design to Manufacture, 1(5), pp. 4-8.

Schroll, A. \& Mild, A. 2011. Open innovation modes and the role of internal R\&D: An empirical study on open innovation adoption in Europe. European Journal of Innovation Management, 14 (4), 475-495.

Seaton, R. A. F. \&Cordey-Hayes, M. 1993. The development and application of interactive models of industrial technology transfer. Technovation, 13 (1), 145-53.

Sieg, J. H., Wallin, M. W. and von Krogh, G. (2010). Managerial challenges in open innovation: a study of innovation intermediation in the chemical industry. $R \& D$ Management, 40 (3), 281-291.

Siggelkow (2007). Persuasion with case studies. Academy of Management Journal, 50(1), 20-24.

Shohet, S. \&Prevezer, M. (1996). "UK biotechnology: institutional linkages, technologytransfer and the role of intermediaries." $R \& D$ Management,26(3), 283-298. 
Stewart, J. \& Hyysalo, S. 2008. Intermediaries, users and social learning in technological innovation. International Journal of Innovation Management, 12 (3), 295-325.

Surowiecki, J. (2004). Wisdom of Crowds: Why the Many Are Smarter Than the Few and How Collective Wisdom Shapes Business, Economies, Societies and Nations.Westminster, MD, USA: Doubleday Publishing.

von Stamm, B. (2008). Managing Innovation, design and creativity, Glasgow, John Wiley\&Sons.

Winch, G. H. \& Courtney, R. 2007. The Organization of Innovation Brokers: An International Review. Technology Analysis \& Strategic Management, 19 (6), 747-763.

Yin, R. K. (2003). Case study research, Thousand Oaks, CA, Sage Publications, Inc. 